anbiances Environnement sensible, architecture et espace urbain Varia | 2015

\title{
Analysing olfactory and auditory sensescapes in English cities: Sensory expectation and urban environmental perception
}

Analyse des environnements olfactifs et auditifs des villes anglaises : expectation sensorielle et perception de l'environnement urbain

Neil Bruce, Jenna Condie, Victoria Henshaw and Sarah R. Payne

\section{OpenEdition}

\section{Journals}

Electronic version

URL: http://journals.openedition.org/ambiances/560

DOI: 10.4000/ambiances.560

ISSN: 2266-839X

Publisher:

Direction Générale des Patrimoines - DAPA - MCC, UMR 1563 - Ambiances Architectures Urbanités (AAU)

Electronic reference

Neil Bruce, Jenna Condie, Victoria Henshaw and Sarah R. Payne, «Analysing olfactory and auditory sensescapes in English cities: Sensory expectation and urban environmental perception », Ambiances [Online], Varia, Online since 31 July 2015, connection on 02 May 2019. URL : http:// journals.openedition.org/ambiances/560 ; DOI : 10.4000/ambiances.560

This text was automatically generated on 2 May 2019.

\section{cc) $(1) \odot$}

Ambiances is licensed under a Creative Commons Attribution-NonCommercial-NoDerivatives 4.0 International License. 


\title{
Analysing olfactory and auditory sensescapes in English cities: Sensory expectation and urban environmental perception
}

\author{
Analyse des environnements olfactifs et auditifs des villes anglaises : expectation \\ sensorielle et perception de l'environnement urbain
}

Neil Bruce, Jenna Condie, Victoria Henshaw and Sarah R. Payne

\section{Introduction}

1 The design of western cities has been argued to place a disproportionate emphasis on the visual appearance and movement of people (Porteous, 1990; Sennett, 1994; Malnar \& Vodvarka, 2004; Zardini, 2005). However, urban ambiances are created and experienced as a product of different, sometimes unique, blends of sights, sounds, smells, textures, tastes and thermal conditions (Thibaud, 2011, p. 204), resonating with our individual and collective memory. In recent years, scholarly activity has provided more detailed illumination on the unique characteristics of the non-visual senses, with this frequently being focussed on individual senses and organised within related scientific and artistic disciplines such as those of acoustics, music, and auditory or olfactory environmental art. Although studies into sensory expectations of consumer products, retail and entertainment environments have emerged, see for example Lindstrom's work across the senses (Lindstrom, 2005), and for more detailed examination of the use and effects of scents and music in marketing service settings: Mattila \& Wirtz (2001) and Spangenberg et al. (2005), research into people's sensory expectations of urban environments and the different types of spaces within them, remains limited. This paper examines the role of expectation with respect to interactions between urban environmental context and perceptions of two specific sensory modes: those of smell and sound. It does so by drawing from, and comparing the findings of two separate, although related studies 
undertaken in English towns and cities, with each of these studies focussing upon one of the examined sensory modes.

The work presented in this paper is positioned between traditional urban analysis and theoretical sensory perception, using a sensory methodology, namely "sensewalks" to obtain the majority of the data presented. There was no in-depth consideration of analytical methods such as economic activity, resource consumption, typology or topology in this work, nor the use of modelling or design tools to investigate elements such as building massing, resource location, space allocation and usage. Instead, human behavior, mobility patterns, and personal space usage were investigated using qualitative interviews, although in the case of the sound study, quantitative data, including sound pressure level $\left(\mathrm{L}_{\text {Aeq }}\right)$ were recorded. This data was used as part of a soundscape simulator, which aimed to test for expectation and perception in a laboratory based environment, to provide a link to a typical urban analysis style approach. The work presented in this paper, was more concerned with an holistic person-centric experience of the environment.

3 It is first useful to outline what is meant here when describing sensory expectation and perception. Expectation is defined in the Oxford Dictionaries (2010) as "a strong belief that something will happen or be the case in the future, or the series of events which are anticipated prior to an experience". Huron (2007) likens expectation to a cliché; a stereotype for a context or situation, and Nikolopoulou and Steemers apply such an understanding of expectation to that of the environmental context describing it as "what the environment should be like, rather than what it actually is" (Nikolopoulou \& Steemers, 2003, p. 97). The term expectation is therefore used in this paper to compare, or draw a distinction between the likelihood of the occurrence of a sensory event or phenomena, and people's anticipation of these occurring within particular environmental contexts. Furthermore, given the focus of this paper upon sensory expectations of ambient urban environments, such sensory encounters are considered with regards to olfactory and auditory aspects of the ambient environment specifically. Put plainly, this paper is interested in what smells and sounds people expect to detect in urban environmental contexts, and in examining how this relates to people's perceptions of the smells and sounds and the environments in which they are, or are not, perceived. The present comparison of smell and sound experiences in urban places is grounded in the data generated from two sensewalks, one focused on smell and one focused on sound. Qualitative insights and themes around 'expectation' of urban sensory experiences emerged from the two qualitative datasets and therefore presented an opportunity for thematic comparison. Other studies such as Diaconu (2011) have also examined two senses, albeit closely related senses of smell and taste. A comparison of qualitative data on smell and sound therefore offered an opportunity to explore the two seemingly unrelated senses in urban contexts.

4 Environmental perception forms part of what Truax (2001) describes as competence or tacit knowledge of the structural relationship between a sensory environment and activity within that environment. These structures relate to the context of an area in which a person is present. Context is defined as the "circumstances that form the setting for an event, statement, or idea, and in terms of which it can be fully understood and assessed" (Oxford Dictionaries, 2010). Rodaway observes that sensory perception has two different meanings across different disciplines (Rodaway, 1994, p. 10-13). These are:

1. perception as the detection of information through the senses and, 
2. perception as mental insight made up of sensory information combined with memories and expectations.

5 This paper therefore takes into account these factors and refers to perception as both the detection of smells and sounds in the urban ambient environment and people's respective mental processing. Sensory perception thus refers to the insights people gain into the physical and socially constructed environment, by attaching meaning through association, following the potential detection and identification of sensory information. However, Engen (1991, p. 86) provides a cautionary note with his observation that "perception is situational, contextual, and ecological" and thus perception of any one smell, and any one sound (Bruce \& Davies, 2009) has the potential to change from place to place according to expectations.

\section{Methodology}

6 This paper draws from two separate, but related, sensewalking studies implemented in English cities. The first of the studies examined expectations of smell in the ambient urban environment in four English towns and cities. These included smellwalks with fiftytwo built environment professionals, business people and local community representatives in the northern English town of Doncaster in 2009, and eighty-two sensory walks with residents in the three cities of Manchester, sheffield and London as part of the Vivacty2020 Project $^{1}$ on urban sustainability in 2004 and 2005 . The second study examined expectations and experiences of sound in the ambient environment, with soundwalks implemented with forty-two built environment professionals, acoustic consultants, local residents and members of the general public in Manchester and London in 2008 and 2009 as part of The Positive Soundscapes Project ${ }^{2}$. Although these two studies followed two separate lines of enquiry, each focused upon one specific sensory aspect of urban ambience i.e. smell and sound, the authors regularly communicated regarding methods, analysis and findings both during and after the studies. Differences and similarities between the studies were examined as they progressed; further developing ideas and understanding regarding the phenomena observed, with those observations regarding expectation being reported in this paper.

7 Sensewalking is described by Adams and Askins (2009) as a varied method by which researchers can "investigate and analyse how we understand, experience and utilise space" and usually involves a researcher walking alone, or with one or more participants through particular, often urban environments, and focussing upon one or more aspect of the sensory environment. The method emerged in the late 1960s and early 1970s and is widely accredited to Schafer and his colleagues at Simon Fraser University. They used soundwalks as a means of exploring and recording urban soundscapes as part of the World Soundscapes Project (Schafer, 1977, 1994). Additionally, credit is given to colleagues at CRESSON in Grenoble, France and their respective work on sonic environments and urban ambiance e.g. Augoyard (1979, 2010), Thibaud (2001) and Thomas (2010). Sensewalks have subsequently been incorporated into a wide range of different studies and are argued to present distinct advantages in examining perceptions of sensory information within the environments within which they are perceived. For more detailed observations on the usefulness of sensewalking in exploring urban soundscapes, see Adams (2009) Bruce and Davies (2009) and Paquette and McCartney (2012); for urban smellscapes, see Bouchard (2013) and Henshaw (2014). 
8 All but six of the sensewalks considered in this paper were undertaken with individuals and were implemented on a pre-determined route with participants asked to focus upon olfactory or auditory information respectively. Each of the walks took between forty-five and ninety minutes and included stopping points in a range of different outdoor urban environments including public urban squares, markets, international districts, primary retail streets and arcades, mixed use areas, green spaces and busy roads. At each of these stopping points, participants were asked questions regarding: the smells or sounds detected both whilst walking and whilst stood within the stopping point area; whether these matched their expectations of the particular areas and the reasons for this; and whether such expectations might change depending upon different times of the day or year. In addition, the fifty-two participants in the smellwalking study in Doncaster were asked to rate their liking of each of the stopping point areas on a five point scale, and their liking of the smells or smell combinations they detected, with the reasons for these ratings being further investigated through qualitative interviewing.

\section{Smell and Sound Expectation}

9 Cities are stereotypically associated with pollution, noise and people, and when questioned prior to undertaking the walks, participants in the two studies were found to associate both the smells and sounds of vehicular traffic, and those of the people moving through them, with urban environments.

“[...] instinctively, you think you can smell pollution, I think that's what you think you're going to smell within a city [...] you expect a dirty smell" (Doncaster, female) "[...] noisy traffic, noisy people, noisy buses, people footsteps, girls with high heels make clack, clack sounds, it's what you'd expect in the city centre" (London participant)

Once undertaking the sensory walks, these clichés urban smells and sounds were detected by all of the participants. Participants detected the smells and sounds of a range of traffic vehicle types (e.g. cars, buses, lorries, taxis and street cleaning vehicles), however, perception varied depending upon environmental characteristics (e.g. the area use, form and typology), and temporality (e.g. the time of the day, week or year). Although traffic fumes and sounds were detected in most areas, they were less dominant in partially or completely pedestrianised areas, with exception to those emitted from the commercial or street cleaning vehicles allowed into these areas. Odours of traffic emissions were almost always perceived negatively: described as related to both the qualities of the odours themselves, the potential for these to harm the body, and the effect these had upon the wider smell environment in the city, "I think it's mainly because of the pollution that you can't smell most of the things" (London, male). The reduced levels of traffic fumes in pedestrianised areas were therefore perceived in widely positive terms, thought to provide an environment where other odours might instead be detected: “...you've got no traffic so you've nothing to conflict with those [more positively perceived odours]... if there are nice smells, they're there for the smelling" (Doncaster, male). Similarly, traffic vehicles provided a low background sound or hum, as opposed to a loud foreground sound, within pedestrianised areas.

11 Although the reduction of vehicular noise provides a key focus for policy aimed at increasing the quality of life afforded within big cities, the sounds of traffic were not 
always perceived in negative terms by participants, and were occasionally considered to provide a positive contribution towards urban ambience,

"I do like comforting sounds of like traffic in the background" (London participant)

"Traffic noise in the distance makes me feel that I am still part of the city and can

re-enter at any point" (Manchester participant)

12 The mixed traffic smells and sounds of taxis, cars and buses revving up, braking or stood still with their engines running, were therefore considered to be distinctive and characteristic of many urban environments, but did have influence upon people's behaviours as they sought to limit their exposure to potentially harmful smell or noise levels.

13 The sounds of people, such as voices, laughter and footsteps were also detected across the different environments and cities examined and were again considered in generally positive terms during the daytime and evening. However although noise and revelry during the night-time provided an exception to this theme, and affective ratings were influenced by participant positionality. For example, revelry and voices are experienced differently when experienced as a reveller in the street as part of the area ambiance, or experienced by people in their residential environments as a potential sleep disturbance:

"[...] we always had drunk students walking past my flat because we lived on the main road between eight o'clock and four in the morning. During the weekends, Friday, Saturday and Sunday I didn't mind because I usually go to sleep quite early, but during the week it would really, really make me angry so I suppose sort of night time noises I find acceptable and almost comforting in a way on a Friday and Saturday night but the rest of the week it really, really grinds me." (London participant)

Odours of people, including their perfumes and body odour, were detected in all of the areas included in the smellwalks at some point, although they were associated and detected more frequently within some areas more than others. Perfumes were, for example, more commonly associated and expected within commercial areas, emitted from both stores and people, or in areas dominated by evening businesses as people paraded in the street:

"I'm thinking this place will be people to-ing and fro-ing between bars and things, you'll be able to smell people and you'll be able to smell maybe aftershave and perfume more definitely" (Doncaster, male)

Food was also found to have an influential effect on place experiences and expectations in both the sound and smellwalk studies, although the effect was more dominant for smell. This related to the odours emitted from: food products themselves such as those being sold, emitted from shops or markets or eaten by people in the street, and, the cooking of food, whether released from stands in the street or released from indoor environments through doors and windows, or mechanical ventilation systems.

Expectations, experiences, and perceptions of both the sounds and smells of food were frequently associated with one-another. The detection of ventilation systems through one of the senses e.g. hearing, smell, sight or haptically (e.g. the feel of a gust of warm air), brought with it an expectation that other forms of sensory information were also likely to be detected:

"I can hear air conditioning [...] which is making me imagine then that there's a smell that's going to come, something's going to get emitted from the air conditioning" (Doncaster, female) 
Market areas were widely associated with a heightened level of a multitude of sensory information such as the competing shouts and cries of the traders marketing their goods and the smells of the fruit, vegetables, fish and meat being sold. When the markets were closed, such areas were often described as suffering from a certain sensory "emptiness", associated with odours of bleach and cleaning products.

Occasionally, odours of construction were associated with cities, however, people were more likely to associate construction sounds such as those of pneumatic drills and hammering with towns and cities than any related smells. Sounds of nature such of those of birdsong, wind and trees blowing were often mentioned, whereas smells of nature were expected more frequently by participants in some cities (London and Sheffield) than others (Manchester and Doncaster). This depended upon the perceived amount of green space and planting within the centres of these respective towns and cities rather than relating to factors of air quality: Doncaster, for example, has superior air quality than the other three cities included in the studies, yet smells of nature were not anticipated within the heart of the town centre due to limited perceived levels of planting.

The findings that expectation of smells and sounds were linked to place expectation, match those of studies in other countries with respect to sound (Guastavino \& Dubois, 2006; Dubois, Guastavino \& Raimbault, 2006). Similarly, those sounds associated with generic urban environments were also detected during the walk and in most areas. In contrast, few previous studies have examined those odours specifically associated with generic urban environments although authors such as Ivan Illich (1986 as cited by Zardini, 2005, 268) outline stereotypical modern smellscapes "[...] increasingly the whole world has come to smell alike: gasoline, detergents, plumbing, and junk foods coalesce into the catholic smog of our age". Whilst walking through the city, participants detected many odours that they had expected of urban environments, however, they also detected a much wider variety of additional odours than they had outlined in a questionnaire before the walk.

\section{Discussion}

In investigating the effects of olfactory and sonic expectation on perception of spaces, it is worth noting here that expectations of both sound and smell have changed over time. Cities have become increasingly noisy places to be, as was highlighted as far back as the 1960's (Southworth, 1969), yet the smell environment has been increasingly controlled through processes of separation, deodorisation, masking and scenting (Rodaway, 1994; Henshaw, 2014). The impact of smell and soundscape is also now influenced by wider forces of globalisation and capitalism. As a result, the variety and strength of manufacturing odours detected in cities today has declined both in number and concentration, accompanied by changing expectations:

"You got smells from factories as well... I think that was the norm, but you accepted it then didn't you, nowadays if you got it you'd think it was different wouldn't you?" (Doncaster, female)

21 People's expectations of the sensory stimuli that they will detect in areas also changes according to the time of the day, week or year. It is also influenced by activities, environmental changes such as local vegetation and animal migration patterns, and climate, which in turn affects people's behaviours. For example, as people open their 
doors and windows out into the street in hotter weather and indoor smell and sound environments bleed out into the street.

The analysis of people's experiences whilst undertaking sensory walks also revealed that smell and sound expectation varied from place to place and between individuals, although there were strong reoccurring themes as summarised in Table 1. Expectations were dependent upon people's prior experiences of specific areas visited, past experiences of similar places or activities undertaken within those areas. This included seemingly mundane observations such as expectations of smells of sawdust outside a petshop or construction site, the sound of voices in highly populated streets or the expectation of bird song in public green areas. It also included more generalised expectations relating to area characteristics such as those associated with "run-down" areas, believed to smell of traffic fumes, grease, smoke, urine and vomit. Areas dominated by the evening economy were also associated with smells of smoke, beer, urine and vomit, as well as sounds of music, shouting and revelry. Other smells and sounds were more specifically associated with particular places such as some of the industrial odours emitted from specific factories or odours of particular markets, distinctive in their strength. As people's expectations were in part dependent on their prior experiences of specific areas, it meant their perceptions were influenced by their memories of these, or similar places. This is in line with the work by Diaconu (2011) who investigated the role of memories in relation to peoples 'smell maps' of the city.

The enjoyment or dislike of odour types varied dramatically between places and was not necessarily related to peoples general affective evaluation for that odour. For example, some participants in Doncaster's smell study suggested that the odours from fish sold at the local fish market, enhanced their experiences of the market place, irrespective of their more general attitudes towards the smell of fish. Odours of fish were both expected and accepted as part of the experience of being in the markets area. In other areas, where people did not expect to detect any specific odours, non-detection was more positively evaluated than in areas where odours were expected.

Over half of the participants in Doncaster's smell study detected odours from fish sold at the local fish market, whilst for the few participants who didn't immediately detect the fish odours, they frequently sought them out. Indeed, participants often sought out expected, but undetected smells, explaining their absence as a consequence of wind direction or temperature. This seeking out of smells coincides with mnemo-perceptive effects of identifying and localising odours. As Balez points out, repeated exposure to smells in a place will "condition the place apprehension" (Balez, 2002, p. 3), thus certain smells are sought out through their anticipation and expectation. If they are absent, such as in the case of the closed market areas, this can change affective evaluations as the place apprehension has not been met.

Conversely, this was met with people actively seeking out soundscapes in cities which matched with their expectations of the spaces, which on the reflection would be normalised to negative perception, but were met with either un-noticed or positive perception. For example, the follow response give example of this expectation from soundwalk participants:

"no it's a city and that's what you would expect, noisy traffic, noisy people, noisy buses, people footsteps... it's what you'd expect in the city centre" (Manchester participant) 
"I like oxford street, the hustle and bustle and the noise of it, it's the essence of what London is about, it's people and noise and activity" (London participant). in these places, as highlighted in a number of the presented quotes. The absence of some of these smells and odours, reflects the difference between the anticipation of the sensory event and the likelihood of the occurence of the event, as participants had not considered the temporal changes that also impact on the presence or absence of a sensory event. For example, no fish smells in the evening when the market is closed, or no smoke, beer, and vomit smells in the daytime walks through evening economy areas. The expectation of these sensory events though demonstrates the strong associations between places and their odours, such that the place can still be strongly associated with particular odours even if they are not detected. Instead, these associations had to be contested on the smellwalks as they frequently varied from these expectations. Effectively this meant that in some areas a lack of odour was perceived incongruent with expectations and thus out of place. These differences between the expectation of an area to smell in a certain way and its actual smell, was also reflected in participants' 'smellscape liking rating' (Henshaw \& Bruce, 2012). As a result, differences occurred in individuals' rating of the same smell when it was experienced within a different environmental context.

soundwalks resulted in many sound expectations being confirmed on a site by site basis, but when these were not met affective evaluations differed to usual. For example, for many participants in a London or Manchester park, the background noise of distant traffic led to a sense of safety and feeling a part of the city, which they could choose to reenter at any point, yet when the traffic sounds were absent, they felt unsafe and the city "felt like a ghost town". In contrast, participants did not expect to hear the sound of birdsong in city centre urban squares, and its presence was perceived positively, once time had been taken to immerse themselves in the space. This element of surprise, in this instance was evaluated positively, however the sound itself cannot be considered completely incongruent with the surroundings, or the identification of the source by the sound alone would have been more difficult, usually due to acoustic masking by other sources. Additionally, hearing unexpected sounds, brought the soundscape into focus, which may subsequently influence place ratings in a negative or positive way depending on the other collection of sounds. Therefore, when the (lack of an) expectation of certain sounds or smells in a particular area was not met, individual smells and sounds might be affectively evaluated differently to normal, and so could the place.

Table 1: A summary of smell/sound expectations in English cities according to area type

\begin{tabular}{|l|l|l|}
\hline Area type & Smells & Sounds \\
\hline Cultural/ International areas & $\begin{array}{l}\text { Foods/spices } \\
\text { Cosmopolitan v foreign odours } \\
\text { Waste }\end{array}$ & $\begin{array}{l}\text { 'Foreign' languages spoken } \\
\text { in the street } \\
\text { Buskers } \\
\text { Bicycles }\end{array}$ \\
\hline
\end{tabular}




\begin{tabular}{|c|c|c|}
\hline Evening Economy dominated areas & $\begin{array}{l}\text { Perfume } \\
\text { Cigarette smoke } \\
\text { Fresh and stale alcohol } \\
\text { Urine/vomit } \\
\text { Take-away/ greasy food } \\
\text { Restaurant smells }\end{array}$ & $\begin{array}{l}\text { Shouting and sounds of } \\
\text { revelry } \\
\text { Loud music } \\
\text { Taxis/cars }\end{array}$ \\
\hline \multirow[t]{2}{*}{$\begin{array}{l}\text { Markets areas (with open market } \\
\text { and closed market) }\end{array}$} & $\begin{array}{l}\text { Strong and varied smells } \\
\text { Food - raw and cooked } \\
\text { Flowers } \\
\text { Non-food products on sale } \\
\text { Smells of people }\end{array}$ & $\begin{array}{l}\text { Loud sound levels } \\
\text { Shouting and voices / cries } \\
\text { of the traders } \\
\text { Clattering } \\
\text { Voice of people }\end{array}$ \\
\hline & Bleach and emptiness & Echoes and emptiness \\
\hline Primary retail streets/areas & $\begin{array}{l}\text { Perfumes } \\
\text { Scented products } \\
\text { Heat curtains } \\
\text { Coffee } \\
\text { (occasionally smell free/clean \& } \\
\text { fresh) }\end{array}$ & $\begin{array}{l}\text { Footsteps and voices } \\
\text { Music } \\
\text { Traffic noise in background } \\
\text { Cleaning machines }\end{array}$ \\
\hline Roads & $\begin{array}{l}\text { Traffic fumes (bus fumes } \\
\text { particularly dominant) } \\
\text { Dirt and dust }\end{array}$ & $\begin{array}{l}\text { Running engines } \\
\text { Screeching breaks } \\
\text { Sirens and horns }\end{array}$ \\
\hline $\begin{array}{l}\text { Run-down/ deprived areas \& } \\
\text { neighbourhoods }\end{array}$ & $\begin{array}{l}\text { Cigarette smoke } \\
\text { Greasy food } \\
\text { Urine/vomit } \\
\text { Traffic fumes } \\
\text { Dirt and dust }\end{array}$ & $\begin{array}{l}\text { Noise from "tramps and } \\
\text { drunks" } \\
\text { Construction work } \\
\text { Alarms } \\
\text { Sirens }\end{array}$ \\
\hline
\end{tabular}

Comparison of the modes of hearing and olfaction raises a number of issues when looking at urban design. Both modalities have been shown within this study to affect how a person interacts and feels when in a space. The modalities and perception of the space also affect if a person would choose to enter a space or remain in a space. What is common between the auditory and the olfactory is how the stimulus does not have to be what may generally be considered 'negative', i.e. a bad smell or a loud noise. In fact, it is the presence of stimuli which are considered unexpected by the person entering the space which affects how they use the space.

The themes that emerged and presented in Table 1 show a classification system by place and not by affective evaluations, as these were shown to vary across places, time, and individuals. However the descriptions highlight the emphasis of people describing and categorising sounds and smells by their source instead of by the effect it has on the individual. This has been observed in other categorisation studies of olfaction and audition (Dubois, 2000) and highlights people's reliance on describing and discussing the non-visual senses by their cause instead of their effect. Moreover due to individual and place variances it would be difficult to develop a small number of themes that can accurately represent the diversity in attitudes towards sources and evaluations of the 
sounds and smells. This is likely to be particularly true when discussing expected sensory events, as people's past experiences and intended actions, which will influence those expectations, will also vary.

31 As the work carried out in this paper looked at the sensory modes individually, it would be fruitful to extend the sensory walking methodology by asking participants to consider mutli-modal aspects. This would help determine how the smell and sound of a space contribute to the person's overall experience of that space, be it negative or positive. Would the design of a flower garden, with associated bird song and water feature be perceived as positive or negative in a city centre environment? Is the vibrant conversation linked with the aroma of freshly ground coffee a factor in the perception of a coffee shop, even though from an acoustic perspective the background noise levels may be what are typically considered as "loud" and thus what maybe considered negative. These questions tie in with research looking at the interplay between senses and how they combine to create unique atmospheres. For example, coffee and cigarette smells, with the contrasting feel of cafe table tops, chairs and cutlery, often accompanied by loud soundscapes in Viennese coffeehouses, as discussed by Mateus-Berr (2011). Indeed, it is the expectation of both sound and smell combined which was noted in the individual studies, which give the sense of place and expectation of that space. If a smell or sound, which was removed from the place norm were present, such as fresh flowers or a crying child, our evidence shows that this would go against expectation, but a comparison of the interaction of both would be useful to see if one affects or influences the other, and changes the nature of the place expectation.

\section{Conclusion}

In both studies, sensewalking facilitated access to participant's views and sensory expectations of various types of environments, offering opportunities to explore differences and similarities between various on-site experiences and responses. The use of the smell and soundwalks also created experiences, providing an immersive and participatory approach. Similar to the early soundwalks undertaken by Schafer (1977, 1994) and Westerkamp (2001), they included an educational element, stimulating responses and facilitating the sharing of ideas and the co-production of knowledge. Reflections on the walks undertaken for this paper by participants, showed that they felt they had learnt and appreciated the urban environment more, and would continue to consider olfactory and auditory experience within urban space. This was particularly pervalent when participants from architects to local planners were taken on walks, as they felt that they had recieved an education experience which would/may inform future design of urban space. A caution should be drawn that whilst from the outset the walking methodolgy aimed to not influence perception, and hoped that participants were having "normal" experiences and responds within the spaces, perception no doubt changed focus as walks progressed, thus benefiting from bringing unconscious thoughts and feelings to the forefront. It would be pervalent for future work to explore how these sensory walks and experiences may futher expand and develop place expectation.

As a result, the authors advocate the more detailed and frequent consideration of sensory aspects of urban ambiance as part of mainstream urban design, development and management practices, also suggesting that attempts to alter or regulate olfactory and aural urban place characteristics, require prior critical reflection. 
We would like to acknowledge our thanks to the University of Salford's Acoustics Research Centre where both PhDs were based, specifically Professor Trevor J. Cox and Dr Andrew Clark who supervised the smell study and Dr Bill Davies for his supervision of the sound study. We would also like to acknowledge the EPSRC for supporting the Vivacity 2020 Project $^{1}$ and The Positive Soundscapes Project ${ }^{2}$ and the University of Manchester for supporting attendance at the 2nd International Congress on Ambiences in Montreal 2012, where a first draft of this paper was presented (Henshaw \& Bruce, 2012)

\section{BIBLIOGRAPHY}

Adams, Mags. 2009. Hearing the city: reflections on soundwalking. Qualitative Researcher 10 (June), Cardiff, University of Cardiff. p. 6-9.

Adams, Mags \& Askins, Kye. 2009. Sensewalking: sensory walking methods for social scientists. RGS-IBG Annual Conference 2009, 26-28 August 2009, Manchester (United Kingdom).

Augoyard, Jean-François. 2010 [1979]. Pas à pas : essai sur le cheminement quotidien en milieu urbain. Grenoble : A la Croisée.

Balez, Suzel. 2002. Characterisation of an existing building according to olfactory parameters. Proceedings from the First International Workshop: Architectural and urban Ambient Environment, Nantes, France [on line]. Available on line at: https://halshs.archives-ouvertes.fr/ halshs-00596759 (consulted on April 26, 2015).

Bouchard, Natalie. 2013. Le théâtre de la mémoire olfactive : le pouvoir des odeurs à modeler notre perception spatiotemporelle de l'environnement. Masters thesis. Montréal : Université de Montréal.

Bruce, Neil; Davies, William J. \& Adams, Mags. 2009. Expectation as a factor in the perception of soundscapes, Euronoise 2009, 26-28 October 2009, Edinburgh (Scotland).

Bruce, Neil \& Davies, William J. 2014. The effects of expectation on the perception of soundscapes, Applied Acoustics, 85. p. 1-11.

Diaconu, Madalina. 2011. City Walks and Tactile Experience. Contemporary Aesthetics 9.

Dubois, Danièle. 2000. Categories as acts of meaning: the case of categories in olfaction and audition. Cognitive Science Quarterly, 1. p. 35-68.

Dubois, Danièle; Guastavino Catherine \& Raimbault Manon. 2006. A cognitive approach to urban soundscapes: using verbal data to access everyday life auditory categories, Acta Acustica united with Acustica 92(2006). S. Hirzel Verlag. p. 865-874.

Engen, Trygg. 1991. Odour Sensation and Memory. New York: Praeger.

Guastavino, Catherine \& Dubois, Danièle. 2006. From Language and Concepts to Acoustics: How do people cognitively process soundscapes? Proceedings of the 35th International Congress and Exposition on Noise Control Engineering, Inter-noise 2006, Honolulu, Hawaii (USA).

Henshaw, Victoria \& Bruce, Niel. 2012. Smell and sound expectation and the ambiances of English cities. In: Thibaud, Jean-Paul \& Siret, Daniel (eds.). 2012. Ambiances in action-Ambiances en actes : Proceedings of the 2nd international congress on ambiances - Actes du 2nd congrès international sur les 
ambiances, Montréal, 19 - 22 septembre 2012. Grenoble : Réseau international Ambiances : École nationale supérieure d'architecture de Grenoble. p. 449-454 [on line]. Available on line at: https://halshs.archives-ouvertes.fr/halshs-00745525/ (consulted on April 27, 2015).

Henshaw, Victoria. 2014. Urban Smellscapes: Understanding and Designing City Smell Environments. Routledge: London and New York.

Huron, David. 2006. Sweet Anticipation: Music and the Psychology of Expectation, Cambridge, Massachusetts: MIT Press.

Lindstrom, Martin. 2005. Brandsense. London: Kogan Page Ltd.

Malnar, Joy Monice \& Vodvarka, Frank. 2004. Sensory Design. Minneapolis: University of Minnesota Press.

Mateus-Berr, Ruth. 2011. Haptic and Olfactory Design Quality of Viennese Coffeehouses. In: Diaconu, Madalina; Heuberger, Eva; Mateus-Berr, Rut \& Vosicky, Lukas, M. (eds.). Senses and the City: An Interdisciplinary Approach to Urban Sensescapes. Wien, Germany: Lit Verlag. p. 77-86.

Mattila, Anna. S. and Wirtz, Jochen. 2001. Congruency of scent and music as a driver of in-store evaluations and behavior. Journal of Retailing, 77. p. 273-289.

Nikolopoulou, Marialena \& Steemers, Koen. 2003. Thermal comfort and psychological adaptation as a guide for designing urban spaces, Energy and Buildings 35(1). p. 95-101.

Oxford Dictionaries. 2010 [on line]. Available on line at:

http://www.oxforddictionaries.com/definition/english/expectation (consulted on April 27, 2015).

Oxford Dictionaries. 2010 [on line]. Available on line at: http://www.oxforddictionaries.com/ definition/english/context (consulted on April 27, 2015).

Paquette, David \& McCartney, Andrea. 2012. Soundwalking and the Bodily Exploration of Places, Canadian Journal of Communication, 37(1). p. 135-145.

Porteous, J. Douglas. 1990. Landscapes of the mind - Worlds of Sense and Metaphor. Toronto: University of Toronto Press.

Rodaway, Paul. 1994. Sensuous Geographies. London: Routledge.

Schafer, Raymond Murray. 1994 [1977]. The Soundscape: Our Sonic Environment and the Tuning of the World, Rochester: Destiny Books.

Sennett, Richard. 1994. Flesh \& Stone. The Body and the City in Western Civilization. London: W.W. Norton \& Company.

Southworth, Michael. 1969. The Sonic Environment of Cities, Environment and Behavior, 1(1). p. 49-70.

Spangenberg, Eric; Grohmann, Bianca \& Sprott, David. E. 2005. It's Beginning to Smell (and sound) a lot like Christmas: The Interactive Effects of Ambient Scent and Music in a Retail Setting. Journal of Business Research, 58. p. 1583-1589.

Thibaud, Jean-Paul. 2001. La méthode des parcours commentés. In : Grosjean, Michèle \& Thibaud, Jean-Paul (eds.). L'espace urbain en méthodes. Marseille : Parenthèses. p. 79-99.

Thibaud, Jean-Paul. 2011. The Sensory Fabric of Urban Ambiances, Senses and Society, 6(2). p. 203-215 [on line]. Available on line at: https://hal.archives-ouvertes.fr/hal-00978343 (consulted on April 27, 2015). 
Thomas, Rachel (eds.). 2010. Marcher en ville, Faire corps, prendre corps, donner corps aux ambiances urbaines. Paris : Archives contemporaines.

Truax, Barry. 2001. Acoustic Communication. 2nd edition. Westport, Connecticut: Ablex Publishing.

Zardini, Mirko (eds.). 2005. Sense of the City - An alternative Approach to Urbanism, Montreal: Lars Muller Publishers.

\section{NOTES}

1. See footnote 1 .

2. See footnote 2 .

\section{ENDNOTES}

1. http://www.vivacity2020.co.uk

2. http://www.salford.ac.uk/computing-science-engineering/research/acoustics/ psychoacoustics/positive-soundscapes-project

\section{ABSTRACTS}

This paper examines the role of sensory expectation in people's experiences and perceptions of a range of different urban environments in English towns and cities by focussing upon those related to smell and sound specifically. It draws from two separate but related sensewalking studies undertaken between 2004 and 2009: one exploring urban smell experiences, the other examining urban sound experiences. In drawing from, and comparing the findings of these two studies, sensory expectations are argued as highly influential in urban place experience and perception, providing different layers of meaning and understanding of place, and presenting challenges and opportunities for architects and urban designers when creating more humancentred places in the city. In addition, perceptions of the smells and sounds themselves are revealed as highly influenced by the environmental context within which they are, or are not, detected. As a result, the authors advocate a more proactive approach to the consideration of smells and sound information when designing and managing urban sensory environments.

Cet article analyse la manière dont les individus perçoivent une gamme variée de stimuli, notamment les sons et les odeurs émis par l'activité humaine, lors de leur déambulation dans les espaces publics des villes anglaises. La démonstration s'appuie sur deux études portant sur la déambulation sensorielle (sensewalking) menées entre 2004 et 2009 indépendamment l'une de l'autre mais avec un objectif identique. La première explore la perception de l'environnement olfactif, tandis que l'autre, s'attarde sur les expériences sonores urbaines. La comparaison des résultats montre que les expectations sensorielles modifient l'attitude des individus dans le milieu urbain en induisant des niveaux de signification et de compréhension variés. Par conséquent, il y a là un défi pour les architectes et les aménageurs de créer des milieux où la prise en compte de ces différents modes de perception pourrait conduire à des réponses plus 
adéquates. Si l'on convient que la perception (ou la non perception) des odeurs et des sons est fortement influencée par l'environnement, il est donc fondamental que le contexte initial soit prise en compte au moment de redéfinir et de gérer les aménagements sensoriels urbains.

\section{INDEX}

Mots-clés: expectation, perception, parcours sensoriel, odeurs, bruits, conception, villes Keywords: expectation, perception, sensewalking, smell, sound, design, cities

\section{AUTHORS}

\section{NEIL BRUCE}

Dr Neil Bruce is a sound designer specialising in sonic branding and urban design, and researcher in the Acoustics Research Centre, University of Salford. His PhD examined the effects of expectation and experience on the perception of soundscapes. Neil has worked as a composer and sound designer in film, television and digital media.

n.s.bruce@salford.ac.uk

\section{JENNA CONDIE}

Dr Jenna Condie is a Lecturer in the School of Social Sciences and Psychology at the University of Western Sydney, Australia. She is a Social Psychologist with interests in place, identity, and environmental conditions. Jenna is a Fellow in Sustainable Urbanisation for the International Social Science Council j.condie@uws.edu.au

\section{VICTORIA HENSHAW}

Dr Victoria Henshaw $(\dagger)$ was a Lecturer in Urban Design and Planning in the Department of Town and Regional Planning, University of Sheffield, UK. She was a specialist in the design and perception of urban sensory environments, author of 'Urban Smellscapes: Understanding and Designing City Smell Environments' (2014) and the blog 'Smell and the City':

https://smellandthecity.wordpress.com

\section{SARAH R. PAYNE}

Dr Sarah Payne is an Assistant Professor of Health in the Built Environment in the School of Energy, Geoscience, Infrastructure, and Society, at Heriot-Watt University, UK. She is an Environmental Psychologist, interested in the multi-sensorial experience of environments, particularly its effect on people's psychological restoration and general wellbeing.

S.R.Payne@hw.ac.uk 